\title{
Design and Synthesis of Two Azete Derivatives Using some Chemical Strategies
}

\author{
Lauro Figueroa-Valverde ${ }^{1, *} \mathbb{D}$, Francisco Díaz-Cedillo ${ }^{2(\mathbb{D})}$, Marcela Rosas-Nexticapa ${ }^{3(\mathbb{D})}$, Maria Virginia \\ Mateu-Armad ${ }^{3(\mathbb{D})}$, Maria López-Ramos ${ }^{1, *(\mathbb{D})}$, Tomas Lopez-Gutierrez ${ }^{1}(\mathbb{D}$, Magdalena \\ Alvarez-Ramirez $^{3}$ (i) , Catalina Cervantes-Ortega ${ }^{3(D)}$, Regina Cauich-Carrillo ${ }^{1(D)}$ \\ 1 Laboratory of Pharmaco-Chemistry, Faculty of Chemical Biological Sciences, University Autonomous of Campeche, Av. \\ Agustín Melgar s/n, Col Buenavista C.P. 24039 Campeche, Camp., México \\ 2 Escuela Nacional de Ciencias Biológicas del Instituto Politécnico Nacional. Prol. Carpio y Plan de Ayala s/n Col. Santo \\ Tomas, D.F. C.P. 11340, México \\ 3 Facultad de Nutrición, Universidad Veracruzana, Médicos y Odontologos s/n C.P. 91010, Unidad del Bosque Xalapa \\ Veracruz, México \\ * Correspondence: lfiguero@uacam.mx (F.V.L); maclopez@uacam.mx (R.N.M);
}

Scopus Author ID 55995915500

Received: 3.07.2021; Revised: 20.08.2021; Accepted: 25.08.2021; Published: 20.10.2021

\begin{abstract}
There are several methods for preparing nitrogen-containing four-membered heterocycles using some reagents that require special conditions such as higher temperatures or differences in the $\mathrm{pH}$. This research aimed to prepare two azete derivatives from 1-Bromo-3,5-dinitrobenzene using some chemical strategies. The chemical structure was characterized by NMR spectroscopic methods. The results indicate that protocols used to synthesize two azete analogs do not require special conditions to give a good yielding. In conclusion, is reported a facile method for the synthesis of two azete derivatives.
\end{abstract}

Keywords: azete; synthesis; four-membered; heterocyclic.

(C) 2021 by the authors. This article is an open-access article distributed under the terms and conditions of the Creative Commons Attribution (CC BY) license (https://creativecommons.org/licenses/by/4.0/).

\section{Introduction}

For several years, heterocycles have been of great interest in both biological and chemical fields [1-4]. In this way, several methods have been used for its preparation., for example, azete derivative synthesis from 4-phenylbenzo-1,2,3-triazine under extreme conditions (420 to $450{ }^{\circ} \mathrm{C}$ ) [5]. Besides, a report showed the intramolecular reaction of $O$-tertpropargylic oximes in the presence of a Chloro(1,5-cyclooctadiene)copper(I) dimer to form an azete- $\mathrm{N}$-oxide [6]. Other data display the preparation of an azete derivative by thermolysis of the cyclopropenyl azide [7]. In addition, an azete derivative was synthesized from $\alpha-(O-$ nitroaryl)benzylphosphonate, potassium tert-butoxide, and tetrahydrofurane [8]. Other data showed the synthesis of an azete analog from a cyclopenta[a]phenanthren-17-one derivative, 4-Nitrophenylacetonitrile, and CopperII chloride [9]. In addition, a 4-sulfoniminoazet-2-amine was prepared using the three-component system (alkyne, sulfonyl azide, and tetramethylguanidine) in the presence of copper(I) iodide [10]. Recently, an azete-steroid derivative was prepared via an intramolecular reaction of methylidene(methylsulfanyl)amine with an alkyne-derivative using copper(II) chloride as catalyst [11]. All these data show several protocols for synthesizing some nitrogen-containing four-membered heterocycles that require 
special conditions such as higher temperatures and different $\mathrm{pHs}$. This study aimed to prepare two azete derivatives using some chemical strategies.

\section{Materials and Methods}

\subsection{General method.}

Starting materials were purchased from commercial suppliers (Sigma-Aldrich). NMR spectra were recorded on a Varian VXR300/5 FT apparatus (300 $\mathrm{MHz} / \mathrm{CDCl}_{3}$ ) using tetramethylsilane as an internal standard. Electron Ionization mass spectrometry (EIMS) was recorded on a Finnigan PolarisQ ion trap mass spectrometer. Melting-point (m.p.) was determined on an electrothermal-900 model apparatus. The infrared spectrum (IR) was determined on a thermo-scientific iSOFT/IR device. Elemental analysis was determined using a PerkinElmer apparatus (Ser. II CHNS / 02400).

\subsection{Synthesis.}

6-(3,5-Dinitro-phenyl)-hex-5-yn-1-ol (2)

A solution of 1-Bromo-3,5-dinitro-benzene (200 mg, $0.81 \mathrm{mmol})$, 5-hexyn-1-ol (100 $\mu 1,0.91 \mathrm{mmol})$, Copper(II) chloride anhydrous (120 mg, $0.89 \mathrm{mmol})$ in methanol $(5 \mathrm{ml})$ was stirring for $48 \mathrm{~h}$ at room temperature. Then the solvent is evaporated on a rotary evaporator and the product is separated using chloroform:hexane (3:1) system; yielding $63 \%$ of product; m.p. 86-88 ${ }^{\circ} \mathrm{C}$; IR $\left(V_{\max }, \quad \mathrm{cm}^{-1}\right) 3400$ and $1542:{ }^{1} \mathrm{H}$ NMR $\left(300 \mathrm{MHz}, \mathrm{CDCl}_{3}-d\right) \delta_{\mathrm{H}}: 1.60-1.62(\mathrm{~m}$, $4 \mathrm{H}), 1.96$ (broad, $1 \mathrm{H}), 2.26-3.64(\mathrm{~m}, 4 \mathrm{H}), 8.52-8.96(\mathrm{~m}, 3 \mathrm{H}) \mathrm{ppm} .{ }^{13} \mathrm{C} \mathrm{NMR}\left(300 \mathrm{~Hz}, \mathrm{CDCl}_{3}\right)$ $\delta_{\mathrm{C}}: 19.70,25.74,31.82,62.20,73.30,88.80,121.32,121.72,135.74,147.92$ ppm. EI-MS m/z: 264.07. Anal. Calcd. for $\mathrm{C}_{12} \mathrm{H}_{12} \mathrm{~N}_{2} \mathrm{O}_{5}$ : C, 54.55; H, 4.58; N, 10.60; O, 30.28. Found: C, 54.52; H, 4.55

11-Nitro-2-oxa-bicyclo[7.3.1]trideca-1(12),9(13),10-trien-7-yne (3)

A solution of compound 2 (200 mg, $0.75 \mathrm{mmol})$, potassium carbonate (110 mg, 0.79 mmol) in dimethyl sulfoxide $(5 \mathrm{ml})$ was stirring for $48 \mathrm{~h}$ at room temperature. Then the solvent is evaporated on a rotary evaporator and the product is separated using the chloroform:agua (3:1) system; yielding $44 \%$ of product; m.p. $66-68{ }^{\circ} \mathrm{C}$; IR $\left(V_{\max }, \mathrm{cm}^{-1}\right) 1542$ and 1210: ${ }^{1} \mathrm{H}$ NMR $\left(300 \mathrm{MHz}, \mathrm{CDCl}_{3}-d\right) \delta_{\mathrm{H}}: 1.00-3.96(\mathrm{~m}, 8 \mathrm{H}), 6.74-7.74(\mathrm{~m}, 3 \mathrm{H}) \mathrm{ppm} .{ }^{13} \mathrm{C} \mathrm{NMR}(300 \mathrm{~Hz}$, $\left.\mathrm{CDCl}_{3}\right) \delta_{\mathrm{C}}: 19.20,25.82,26.64,67.34,76.42,89.92,108.72,118.60,122.96,125.92,144.10$, 155.72 ppm. EI-MS m/z: 217.07. Anal. Calcd. for $\mathrm{C}_{12} \mathrm{H}_{11} \mathrm{NO}_{3}: \mathrm{C}, 66.35 ; \mathrm{H}, 5.10 ; \mathrm{N}, 6.45 ; \mathrm{O}$, 22.10. Found: C, 66.32; H, 5.08.

1-(2-Oxa-bicyclo[7.3.1]trideca-1(12),9(13),10-trien-7-yn-11-yloxy)-naphthalen-2-ol (4)

A solution of compound $\mathbf{3}$ (200 mg, $0.92 \mathrm{mmol}$ ), 1-Nitro-naphthalen-2-ol (175 mg, 0.92 $\mathrm{mmol})$, potassium carbonate $(130 \mathrm{mg}, 0.93 \mathrm{mmol})$ in dimethyl sulfoxide $(5 \mathrm{ml})$ was stirring for $48 \mathrm{~h}$ at room temperature. Then the solvent is evaporated on a rotary evaporator and the product is separated using the chloroform:hexane:benzene (3:1:1) system; yielding 52\% of product; m.p. $120-122{ }^{\circ} \mathrm{C}$; IR $\left(V_{\max }, \mathrm{cm}^{-1}\right) 3402$ and $1212:{ }^{1} \mathrm{H}$ NMR $\left(300 \mathrm{MHz}, \mathrm{CDCl}_{3}-d\right) \delta_{\mathrm{H}}: 1.00-3.96$ $(\mathrm{m}, 8 \mathrm{H}), 6.34-6.64(\mathrm{~m}, 3 \mathrm{H}), 6.89$ (broad, $1 \mathrm{H}), 7.22-8.10(\mathrm{~m}, 6 \mathrm{H}) \mathrm{ppm} .{ }^{13} \mathrm{C} \mathrm{NMR}(300 \mathrm{~Hz}$, $\left.\mathrm{CDCl}_{3}\right) \delta_{\mathrm{C}}: 19.20,25.80,26.62,67.34,78.36,89.92,107.22,112.42,117.42,119.22,120.72$, 
121.92, 124.74, 124.82, 125.09, 126.12, 126.49, 129.90, 134.16, 146.10, 161.72, 162.10 ppm. EI-MS m/z: 330.12. Anal. Calcd. for $\mathrm{C}_{22} \mathrm{H}_{18} \mathrm{O}_{3}$ : C, 79.98; H, 5.49; O, 14.53. Found: C, 79.95; H, 5.46 .

11-[2-(1-Phenyl-but-3-enyloxy)-naphthalen-1-yloxy]-2-oxa-bicyclo[7.3.1]trideca$1(12), 9(13), 10$-trien-7-yne (5)

A solution of compound 4 (200 mg, $0.60 \mathrm{mmol})$, 1-Phenyl-but-3-en-1-ol (110 $\mu 1,0.73$ $\mathrm{mmol})$, potassium carbonate $(130 \mathrm{mg}, 0.93 \mathrm{mmol})$ in dimethyl sulfoxide $(5 \mathrm{ml})$ was stirring for $48 \mathrm{~h}$ at room temperature. Then the solvent is evaporated on a rotary evaporator and the product is separated using the chloroform:agua (4:1) system; yielding 48\% of product; m.p. 110-112 ${ }^{\circ} \mathrm{C}$; IR $\left(V_{\max }, \mathrm{cm}^{-1}\right) 1582$ and 1212: ${ }^{1} \mathrm{H}$ NMR $\left(300 \mathrm{MHz}, \mathrm{CDCl}_{3}-d\right) \delta_{\mathrm{H}}: 1.00-2.00(\mathrm{~m}, 6 \mathrm{H}), 2.18-$ $2.34(\mathrm{~m}, 2 \mathrm{H}), 3.90-3.96(\mathrm{~m}, 2 \mathrm{H}), 4.96(\mathrm{~m}, 1 \mathrm{H}), 5.14-5.90(\mathrm{~m}, 3 \mathrm{H}), 6.36-6.66(\mathrm{~m}, 3 \mathrm{H}), 7.20-$ $7.40(\mathrm{~m}, 3 \mathrm{H}), 7.44(\mathrm{~m}, 1 \mathrm{H}), 7.48(\mathrm{~m}, 2 \mathrm{H}), 7.60-8.10(\mathrm{~m}, 5 \mathrm{H}) \mathrm{ppm} .{ }^{13} \mathrm{C}$ NMR $\left(300 \mathrm{~Hz}, \mathrm{CDCl}_{3}\right)$ $\delta_{\mathrm{C}}: 19.20,25.80,26.62,44.22,67.34,78.36,81.37,89.92,107.95,113.14,114.46,117.40$, $118.66,119.98,122.16,122.80,123.70,125.02,126.54,127.74,127.96,128.32,129.85$, 132.30, 138.66, 141.70, 149.92, 151.00, 161.64, 163.14 ppm. EI-MS m/z: 460.20. Anal. Calcd. for $\mathrm{C}_{32} \mathrm{H}_{28} \mathrm{O}_{3}$ : C, 83.45; H, 6.13; O, 10.42. Found: C, 83.42; H, 10.40 .

11-(2-Hex-5-ynyloxy-naphthalen-1-yloxy)-2-oxa-bicyclo[7.3.1]trideca-1(12),9(13),10-trien7 -yne (6)

A solution of compound 4 (200 mg, $0.60 \mathrm{mmol})$, 5-hexyn-1-ol $(70 \mu \mathrm{l}, 0.63 \mathrm{mmol})$ potassium carbonate $(70 \mathrm{mg}, 0.50 \mathrm{mmol})$ in dimethyl sulfoxide $(5 \mathrm{ml})$ was stirring for $48 \mathrm{~h}$ at room temperature. Then the solvent is evaporated on a rotary evaporator and the product is separated using the chloroform:hexane (3:1) system; yielding 54\% of product; m.p. 134-136 ${ }^{\circ} \mathrm{C}$; IR $\left(V_{\max }, \mathrm{cm}^{-1}\right) 2138$ and 1210: ${ }^{1} \mathrm{H}$ NMR $\left(300 \mathrm{MHz}, \mathrm{CDCl}_{3}-d\right) \delta_{\mathrm{H}}: 1.00(\mathrm{~m}, 2 \mathrm{H}), 1.62-1.84$ $(\mathrm{m}, 4 \mathrm{H}), 1.94(\mathrm{~s}, 1 \mathrm{H}), 1.96-2.00(\mathrm{~m}, 3 \mathrm{H}), 2.22(\mathrm{~m}, 2 \mathrm{H}), 3.94-3.96(\mathrm{~m}, 2 \mathrm{H}), 4.20(\mathrm{~m}, 2 \mathrm{H}), 6.36-$ $6.66(\mathrm{~m}, 3 \mathrm{H}), 7.40-8.10(\mathrm{~m}, 6 \mathrm{H}) \mathrm{ppm} .{ }^{13} \mathrm{C} \mathrm{NMR}\left(300 \mathrm{~Hz}, \mathrm{CDCl}_{3}\right) \delta_{\mathrm{C}}: 18.06,19.20,25.02$, 25.80, 26.62, 28.94, 67.34, 68.62, 70.22, 78.44, 84.13, 89.89, 107.92, 113.14, 117.40, 117.76, 119.94, 122.00, 123.86, 123.92, 126.54, 128.32, 129.88, 130.80, 148.96, 150.78 161.64, 163.30 ppm. EI-MS m/z: 410.18. Anal. Calcd. for $\mathrm{C}_{28} \mathrm{H}_{26} \mathrm{O}_{3}$ : C, 81.92; H, 6.38; O, 11.69. Found: C, $81.90 ; \mathrm{H}, 6.35$.

\{4-[1-(2-Oxa-bicyclo[7.3.1]trideca-1(12),9(13),10-trien-7-yn-11-yloxy)-naphthalen-2-yloxy]phe-nyl $\}$-acetonitrile (7)

A solution of compound 4 (200 mg, $0.60 \mathrm{mmol}$ ), (4-Nitro-phenyl)-acetonitrile (100 mg, $0.61) \mathrm{mmol}$ potassium carbonate $(70 \mathrm{mg}, 0.50 \mathrm{mmol})$ in dimethyl sulfoxide $(5 \mathrm{ml})$ was stirring for $48 \mathrm{~h}$ at room temperature. Then the solvent is evaporated on a rotary evaporator and the product is separated using the hexane:methanol (1:2) system; yielding 55\% of product; m.p. $108.110{ }^{\circ} \mathrm{C}$; IR $\left(V_{\max }, \mathrm{cm}^{-1}\right) 3320$ and $1212:{ }^{1} \mathrm{H}$ NMR $\left(300 \mathrm{MHz}, \mathrm{CDCl}_{3}-d\right) \delta_{\mathrm{H}}: 1.00-2.00(\mathrm{~m}$, $6 \mathrm{H}), 3.62(\mathrm{~m}, 2 \mathrm{H}), 3.92-6.72(\mathrm{~m}, 5 \mathrm{H}), 7.22-7.35(\mathrm{~m}, 4 \mathrm{H}), 7.50-8.22(\mathrm{~m}, 6 \mathrm{H}) \mathrm{ppm} .{ }^{13} \mathrm{C} \mathrm{NMR}$ $\left(300 \mathrm{~Hz}, \mathrm{CDCl}_{3}\right) \delta_{\mathrm{C}}: 19.20,23.42,25.80,26.63,67.38,78.42,89.92,104.00,109.23,115.82$, $117.30,117.40,117.44,121.45,122.46,122.54,123.10,123.94,124.34,125.12,125.62$, 125.68, 126.20, 136.30, 143.84, 157.52, 161.80, 164.32 ppm. EI-MS m/z: 445.16. Anal. Calcd. for $\mathrm{C}_{30} \mathrm{H}_{23} \mathrm{NO}_{3}$ : C, 80.88; H, 5.20; N, 3.14; O, 10.77. Found: C, 80.85; H, 5.17. 
2-[2-[[1-(2-oxabicyclo[7.3.1]trideca-1(12),9(13),10-trien-7-yn-11-yloxy)-2-na-phthyl]oxy]2-phe-nyl-ethyl]-4-[[4-[[1-(2-oxabicyclo[7.3.1]trideca-1(12),9(13),10-trien-7-yn-11-yloxy)-2naphthyl] oxy]phenyl]methyl]-2,3-dihydroazete (8)

A solution of compound 5 (200 mg, $0.43 \mathrm{mmol}$ ), compound 7 (195 mg, $0.43 \mathrm{mmol}$ ), Copper(II) chloride $(120 \mathrm{mg}, 0.89 \mathrm{mmol})$ in methanol $(5 \mathrm{ml})$ was stirring for $48 \mathrm{~h}$ at room temperature. Then the solvent is evaporated on a rotary evaporator and the product is separated using the chloroform:agua (4:1) system; yielding $65 \%$ of product; m.p. $144-146{ }^{\circ} \mathrm{C}$; IR ( $V_{\max }$, $\left.\mathrm{cm}^{-1}\right) 3320$ and 1212: ${ }^{1} \mathrm{H}$ NMR $\left(300 \mathrm{MHz}, \mathrm{CDCl}_{3}-d\right) \delta_{\mathrm{H}}: 1.00-1.96(\mathrm{~m}, 8 \mathrm{H}), 1.98(\mathrm{~m}, 1 \mathrm{H}), 2.00$ $(\mathrm{m}, 2 \mathrm{H}), 2.26(\mathrm{~m}, 1 \mathrm{H}), 2.32-2.82(\mathrm{~m}, 4 \mathrm{H}), 3.56(\mathrm{~m}, 2 \mathrm{H}), 3.92-3.96(\mathrm{~m}, 2 \mathrm{H}), 4.66-5.06(\mathrm{~m}, 3 \mathrm{H})$, $5.50(\mathrm{~m}, 1 \mathrm{H}), 5.70(\mathrm{~m}, 1 \mathrm{H}), 6.30-6.72(\mathrm{~m}, 5 \mathrm{H}), 6.88-6.96(\mathrm{~m}, 4 \mathrm{H}), 7.32(\mathrm{~m}, 3 \mathrm{H}), 7.42-7.50(\mathrm{~m}$, $2 \mathrm{H}), 7.52(\mathrm{~m}, 2 \mathrm{H}), 7.60-8.26(\mathrm{~m}, 10 \mathrm{H}) \mathrm{ppm} .{ }^{13} \mathrm{C} \mathrm{NMR}\left(300 \mathrm{~Hz}, \mathrm{CDCl}_{3}\right) \delta_{\mathrm{C}}: 19.20,25.80$, 26.62, 33.42, 40.32, 42.70, 45.96, 67.34, 78.42, 79.24, 89.92, 104.00, 107.98, 109.22, 113.16, $114.70,115.82,117.44,118.34,119.94,121.42,122.12,122.54,122.81,123.13123 .70$, $124.31,124.37,125.12,125.62,125.68,125.80,126.22,126.52,126.60,127.60,128.34$, $129.16,129.82$, 133.10, 136.30, 139.92, 143.86, 149.58, 151.00, 157.54, 161.64, 162.10, 164.26, 166.02 ppm. EI-MS m/z: 905.37. Anal. Calcd. for $\mathrm{C}_{62} \mathrm{H}_{51} \mathrm{NO}_{6}: \mathrm{C}, 82.19 ; \mathrm{H}, 5.67$; N, 1.55; O, 10.59. Found: C, 82.16; H, 5.64.

2-[4-[[1-(2-oxabicyclo[7.3.1]trideca-1(12),9(13),10-trien-7-yn-11-yloxy)-2-naphthyl]oxy]butyl]-4-[[4-[[1-(2-oxabicyclo[7.3.1]trideca-1(12),9(13),10-trien-7-yn-11-yloxy)-2naphthyl]oxy]phenyl]methyl]azete (9)

A solution of compound 6 (200 mg, $0.48 \mathrm{mmol}$ ), compound 7 (220 mg, $0.48 \mathrm{mmol}$ ), Copper(II) chloride $(120 \mathrm{mg}, 0.89 \mathrm{mmol})$ in methanol $(5 \mathrm{ml})$ was stirring for $48 \mathrm{~h}$ at room temperature. Then the solvent is evaporated on a rotary evaporator and the product is separated using the chloroform:agua (4:1) system; yielding $63 \%$ of product; m.p. $128-130{ }^{\circ} \mathrm{C}$; IR ( $V_{\max }$, $\left.\mathrm{cm}^{-1}\right) 33222$ and 1210: ${ }^{1} \mathrm{H}$ NMR $\left(300 \mathrm{MHz}, \mathrm{CDCl}_{3}-d\right) \delta_{\mathrm{H}}: 1.00-1.30(\mathrm{~m}, 4 \mathrm{H}), 1.52(\mathrm{~m}, 2 \mathrm{H})$, $1.62(\mathrm{~m}, 2 \mathrm{H}), 1.68(\mathrm{~m}, 2 \mathrm{H}), 1.94-2.35(\mathrm{~m}, 6 \mathrm{H}), 2.72(\mathrm{~m}, 2 \mathrm{H}), 2.82(\mathrm{~m}, 2 \mathrm{H}), 3.70(\mathrm{~m}, 2 \mathrm{H}), 3.90-$ $3.94(\mathrm{~m}, 2 \mathrm{H}), 4.12(\mathrm{~m}, 2 \mathrm{H}), 4.96(\mathrm{~d}, 1 \mathrm{H}, \mathrm{J}=1.79 \mathrm{~Hz}), 5.50-6.74(\mathrm{~m}, 6 \mathrm{H}), 6.90-6.96(\mathrm{~m}, 4 \mathrm{H})$, 7.40-8.28 (m, 12H) ppm. ${ }^{13} \mathrm{C} \mathrm{NMR}\left(300 \mathrm{~Hz}, \mathrm{CDCl}_{3}\right) \delta_{\mathrm{C}}: 19.20,21.90,25.80,26.62,28.00$, $31.34,45.54,67.34,68.50,78.36,89.92,104.00,107.95,109.20,111.34,113.12,115.70$, $115.84,117.42,117.78,119.94,121.42,122.00,122.54,123.12,123.84,123.92,124.37$, $125.12,125.62,125.68,126.17,126.20,126.50,126.55,128.34,129.92,130.80136 .30$, 143.87, 148.96, 150.74, 153.60, 157.54, 161.64, 162.08, 163.32, 164.24, 165.90 ppm. EI-MS m/z: 445.16. Anal. Calcd. for $\mathrm{C}_{58} \mathrm{H}_{49} \mathrm{NO}_{6}: \mathrm{C}, 81.38 ; \mathrm{H}, 5.77 ; \mathrm{N}, 1.64 ; \mathrm{O}, 11.21$. Found: $\mathrm{C}$, 81.35; H, 5.74 .

\subsection{Physicochemical properties.}

Theoretical electronic parameters, such as HOMO (highest occupied molecular orbital), LUMO (lowest unoccupied molecular orbital) energy, orbital coefficients distribution, molecular dipole moment, HBD (hydrogen bond donor groups), HBA (hydrogen bond acceptor groups), and TPSA (topological polar surface area) were evaluated using SPARTAN (v.1.4) software [12-15]. 


\subsection{Pharmacophore model.}

The 3D-pharmacophore model for both compounds 8 and 9 was determined using LigandScout 4.08 software [16-18].

\section{Results and Discussion}

There are some protocols for the synthesis of some azete derivatives which require special conditions [5-11]. Analyzing these data, this study aimed to prepare two azete analogs using some chemical tools as follows:

\subsection{Coupling of terminal alkynes with benzyl bromide.}

There are several studies for the addition of benzyl halide to terminal alkyne using several reagents such as $\mathrm{CuI}$ [19], SIMesCuCl [20], Gold(I) [21], Pd/Ni [22]. However, some protocols require different $\mathrm{pH}$ and high temperatures. In this investigation, 1-Bromo-3,5dinitro-benzene reacted with 5-hexyn-1-ol (in the presence of Copper(II) chloride (Figure 1) to form the hexynol (2). The ${ }^{1} \mathrm{H}$ NMR spectra from 2 showed different bands at 1.00-1.62 and 2.26-3.64 ppm for methylene groups bound to both alkyne and hydroxyl groups; at $1.96 \mathrm{ppm}$ for hydroxyl group; at 8.52-8.96 ppm for phenyl group. ${ }^{13} \mathrm{C}$ NMR spectra showed chemical shifts at $19.70-62.20 \mathrm{ppm}$ for methylene groups bound to both alkyne and hydroxyl groups; at 73.30-88.80 ppm for alkyne group; at 121.32-147.92 ppm for phenyl group. Besides, the mass spectrum from 2 displays a molecular ion $(\mathrm{m} / \mathrm{z})$ at 264.07.

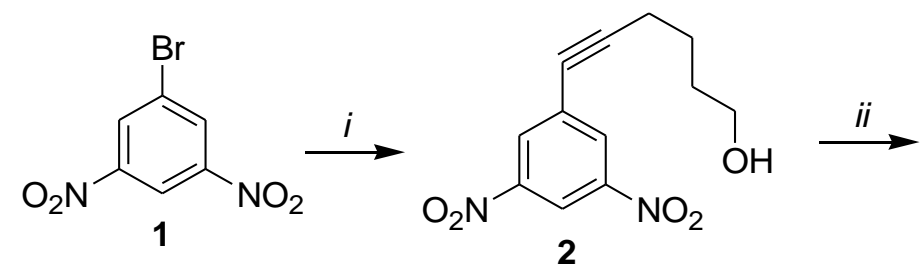<smiles>C#Cc1cc(OCCCCC)cc([N+](=O)[O-])c1</smiles><smiles>N#Cc1cc(C#CCCCCOc2ccccc2)cc(Oc2c(O)ccc3ccc(C#N)cc23)c1</smiles>

Figure 1. Synthesis of an naphthalenol derivative (4). Reagents and conditions: $i=$ 5-hexyn-1-ol, (Copper(II) chloride, $\mathrm{MeOH}$, room temperature; $i i=\mathrm{K}_{2} \mathrm{CO}_{3}$, DMSO, room temperature; $i i i=1$-Nitro-naphthalen-2-ol, $\mathrm{K}_{2} \mathrm{CO}_{3}$, DMSO, room temperature. DMSO = dimethyl sulfoxide.

\subsection{Preparation of ether derivatives.}

Several methods have been employed to the synthesis of some ether analogs using different reagents, such as $p$-toluenesulfonic acid [23], Tetrabutylammonium bromide [24], $\mathrm{Cu} / \mathrm{ZnO} / \mathrm{ZrO}_{2}$ [25], lithium aluminum hydride [26]. Besides, other reports have shown the synthesis of ether derivatives via the nitro group's displacement in the presence of dimethyl sulfoxide [27]. In the first stage, compound $\mathbf{3}$ was prepared from compounds $\mathbf{2}$ and dimethyl sulfoxide in mild conditions. (Figure 1). The ${ }^{1} \mathrm{H}$ NMR spectra from 3 different display bands at 1.00-3.96 ppm for methylene groups linked to both alkyne and ether groups; at 6.74-7.74 
ppm for phenyl group. ${ }^{13} \mathrm{C}$ NMR spectra showed chemical shifts at 19.20-89.92 for methylene groups bound to both alkyne and ether groups; at 108.72-155.72 ppm for phenyl group. In addition, the mass spectrum from $\mathbf{3}$ displays a molecular ion $(\mathrm{m} / \mathrm{z})$ at 217.07.

The second stage was achieved through reaction of $\mathbf{3}$ with 1-Nitro-naphthalen-2-ol in the presence of dimethylsulfoxide to form compound 4 (Figure 1). The ${ }^{1} \mathrm{H}$ NMR spectra from 4 showed several signals at 1.00-6.64 ppm for 2-Oxa-bicyclo[7.3.1]trideca-1(12),9(13),10trien-7-yne fragment; at $6.89 \mathrm{ppm}$ for hydroxyl group; at 7.22-8.10 ppm for naphthalene fragment. ${ }^{13} \mathrm{C}$ NMR spectra showed chemical shifts at 19.20-117.42, 126.90 and 161.72$162.10 \mathrm{ppm}$ for 2-Oxa-bicyclo[7.3.1]trideca-1(12),9(13),10-trien-7-yne fragment; at 119.22126.49 and 134.16-146.10 ppm for naphthalene fragment. Additionally, the mass spectrum from 4 displays a molecular ion $(\mathrm{m} / \mathrm{z})$ at 330.12 .

The third stage involves the synthesis of compounds 5 from 4 and 1-Phenyl-but-3-en1-ol, dimethyl sulfoxide in mild conditions (Figure 2).

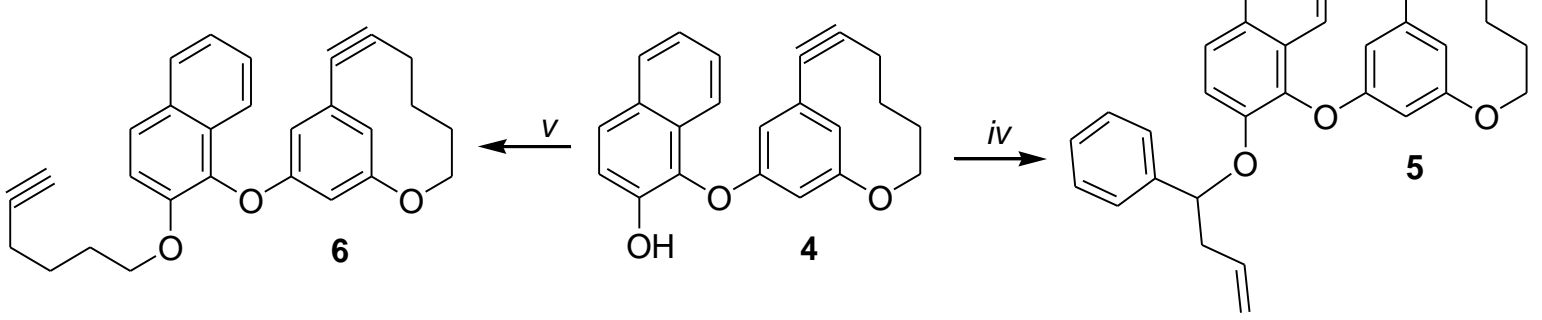

Figure 2. Synthesis of two 2-oxa-bicyclo[7.3.1]trideca-1(12),9(13),10-trien-7-yne derivatives (5 and 6 ).

Reagents and conditions: iv = 1-Phenyl-but-3-en-1-ol, $\mathrm{K}_{2} \mathrm{CO}_{3}, \mathrm{DMSO}$, room temperature; $v=5$-hexyn-1-ol, $\left(\mathrm{K}_{2} \mathrm{CO}_{3}\right.$, DMSO, dimethyl sulfoxide, room temperature. DMSO, dimethyl sulfoxide

The ${ }^{1} \mathrm{H}$ NMR spectra from 5 showed several signals at 1.00-2.00, 3.90-3.96 and 6.36$6.66 \mathrm{ppm}$ for 2-Oxa-bicyclo[7.3.1]trideca-1(12),9(13),10-trien-7-yne fragment; at 2.18-2.34 and 4.96 for methylene groups bound to both alkene and phenyl groups; at 5.14-5.90 for alkene group; at 7.20-7.40 and 7.48 ppm for phenyl group; at 7.44 and 7.60-8.10 ppm for naphthalene fragment. ${ }^{13} \mathrm{C}$ NMR spectra showed chemical shifts at 19.20-26.62, 67.34-78.36, 89.92-113.14, 117.40, 129.85 and 161.64-163.14 for 2-Oxa-bicyclo[7.3.1]trideca-1(12),9(13),10-trien-7-yne fragment; at 44.22 and $81.37 \mathrm{ppm}$ for methylene groups linked to both alkene and phenyl groups; at 114.46, 141.70 ppm for alkene group; at 118.66-123.70, 126.54, 128.32, 132.30 and 149.92-151.00 ppm for naphthalene fragment; at 125.02, 127.74-127.96 and $138.66 \mathrm{ppm}$ for phenyl group. Besides, the mass spectrum from 5 displays a molecular ion (m/z) at 460.20.

The fourth stage was achieved through of reaction of 4 with 5-hexyn-1-ol in the presence of dimethyl sulfoxide to form compound 6 (Figure 2). The ${ }^{1} \mathrm{H}$ NMR spectra from 6 showed several signals at 1.00-2.00, 3.94-3.96 and 6.36-6.66 ppm for 2-Oxabicyclo[7.3.1] trideca-1(12),9(13),10-trien-7-yne fragment; at 1.62-1.84, 2.22 and 4.20 ppm for methylene groups linked to both ether and alkyne groups; at $1.94 \mathrm{ppm}$ for alkyne group; at 7.40-8.10 ppm for naphthalene fragment. ${ }^{13} \mathrm{C}$ NMR spectra showed chemical shifts at 18.05, 25.02-28.94 and $70.22 \mathrm{ppm}$ for methylene groups bound to both ether and alkyne groups; at $19.20,25.80-26.62,67.34,78.44,89.89-117.40,129.88$ and 161.64-163.30 ppm for 2-Oxabicyclo[7.3.1]trideca-1(12),9(13),10-trien-7-yne fragment; at 68.62 and $84.13 \mathrm{ppm}$ for alkyne group; at 117.76-128.32 and 130.80-150.78 ppm for naphthalene group. Finally, the mass spectrum from 6 displays a molecular ion $(\mathrm{m} / \mathrm{z})$ at 410.18 .

The fifth stage involves the reaction of 4 with 1-Nitro-4-prop-2-ynyl-benzene in the presence of dimethyl sulfoxide to form compound 7 (Figure 3). 


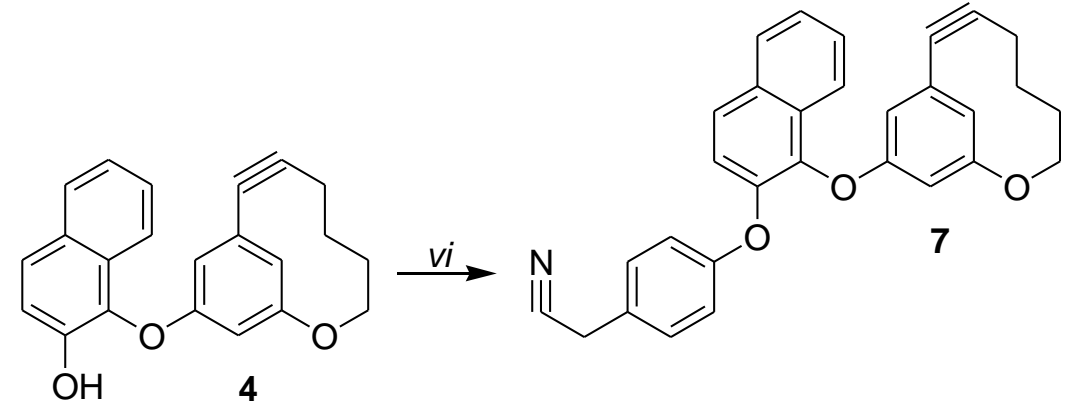

Figure 3. Synthesis of a naphthalen-2-yloxy]-phenyl $\}$-acetonitrile derivative (7). Reagents and conditions: $v i=$ (4-Nitro-phenyl)-acetonitrile, $\mathrm{K}_{2} \mathrm{CO}_{3}$, DMSO, room temperature. DMSO, dimethyl sulfoxide

The ${ }^{1} \mathrm{H}$ NMR spectra from 7 showed several signals at 1.00-2.00 and 3.92-6.72 ppm for 2-Oxa-bicyclo[7.3.1]trideca-1(12),9(13),10-trien-7-yne fragment; at $3.62 \mathrm{ppm}$ for methylene group bound to both cyanide and phenyl groups; at 7.22-7.35 ppm for phenyl group; at 7.50$8.22 \mathrm{ppm}$ for naphthalene fragment. ${ }^{13} \mathrm{C}$ NMR spectra showed chemical shifts at 19.20, 25.80109.23, 117.44, 125.68 and 157.52-164.32 ppm for 2-Oxa-bicyclo[7.3.1]trideca1(12),9(13),10-trien-7-yne fragment; at $23.42 \mathrm{ppm}$ for methylene bound to both phenyl and cyanide groups; at 115.12, 121.45, 122.54-123.10, 124.34-125.62 and 126.20-143.84 ppm for naphthalene fragment; at 117.30, 122.46 and 123.94 for phenyl group; at 117.40 for cyanide group. Besides, the mass spectrum from 7 displays a molecular ion $(\mathrm{m} / \mathrm{z})$ at 445.16 .

\subsection{Synthesis of an azetidine derivative.}

There are some methods for the synthesis of azetidine derivatives using some reagents such as Copper(II) chloride [11], tetrakis(acetonitrile)copper(I) tetrafluoroborate [28], 1azabicyclo[1.1.0]butanes [29], p-toluenesulfonyl chloride [30]. This stage was achieved by preparing compound $\mathbf{8}$ via reaction of $\mathbf{5}$ with compound $\mathbf{7}$ using Copper(II) chloride as catalyst (Figure 4).
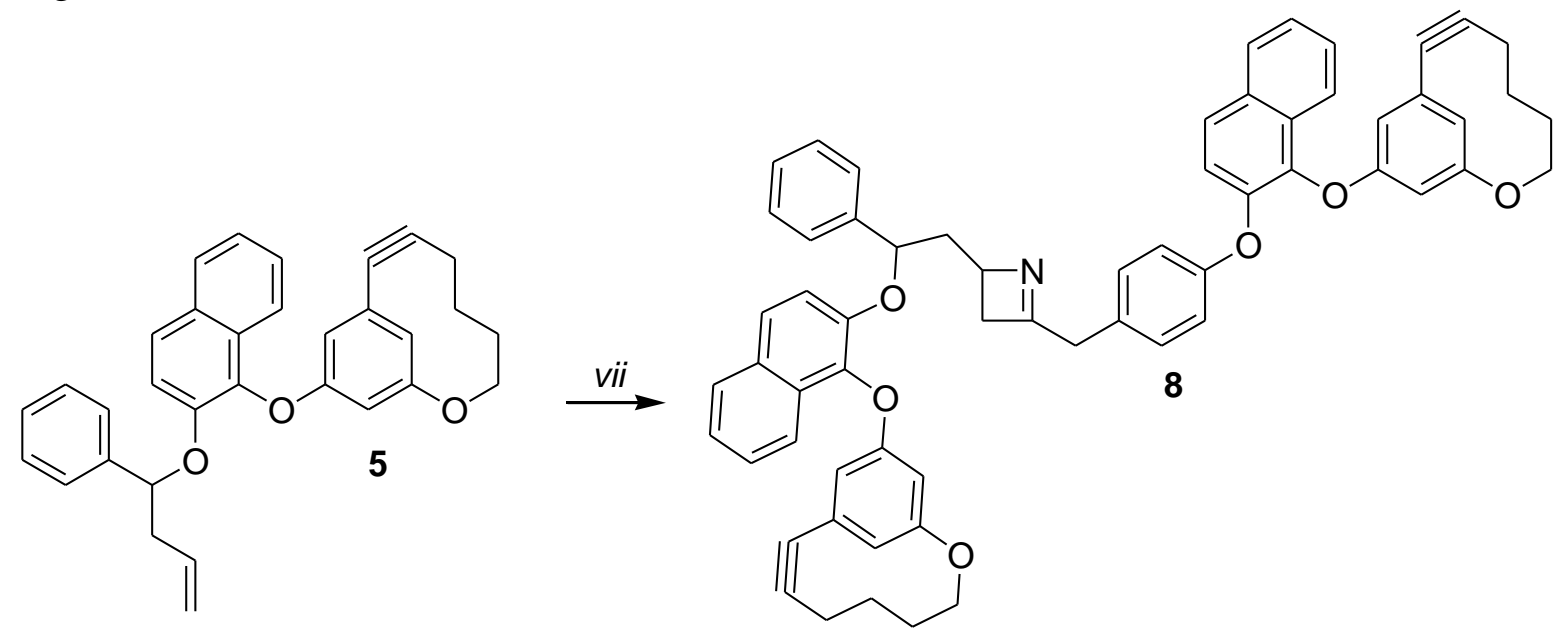

Figure 4. Synthesis of a 2,3-dihydro-azete derivative (8). Reagents and conditions: vii=2-oxabicyclo[7.3.1]trideca-1(12),9(13),10-trien-7-yne derivative (5), naphthalen-2-yloxy]-phenyl\}-acetonitrile derivative (7), Copper(II) chloride, room temperature.

The ${ }^{1} \mathrm{H}$ NMR spectra from 8 showed several signals at 1.00-11.96, 2.00, 2.32-2.82, 3.92-3.96, 5.50, 6.30-6.72 and 7.42-7.50 ppm for 2-Oxa-bicyclo[7.3.1]trideca-1(12),9(13),10trien-7-yne fragments; at 1.98, 2.26 and $5.70 \mathrm{ppm}$ for methylene groups bound to both azete ring and ether groups; at $3.56 \mathrm{ppm}$ for phenyl group linked to methylene group; at 4.66-5.06 
ppm for azete ring; at 6.88-6.96, 7.32 and $7.52 \mathrm{ppm}$ for phenyl groups bound to ether groups at 7.60-8.26 ppm for naphthalene fragment. ${ }^{13} \mathrm{C}$ NMR spectra showed chemical shifts at 19.2026.62, 67.34-78.42, 88.92-113.16, 117.44, 125.68, 129.82, 157.54-161.64 and 164.26 ppm for for 2-Oxa-bicyclo[7.3.1]trideca-1(12),9(13),10-trien-7-yne fragments; at 40.32, 45.96 and $79.24 \mathrm{ppm}$ for phenyl groups linked to ether groups; at 114.70, 125.80, 126.60 and $162.10 \mathrm{ppm}$ for phenyl group bound to ether group; at 115.82, 118.34-123.70, 124.37-125.62 126.22$126.52,128.34,133.10-136.30$ and $143.86-151.00$ ppm for naphthalene fragments; at 124.31, $127.60,129.16$ and 139.92 for phenyl group bound to methylene group. In addition, the mass spectrum from 8 displays a molecular ion $(\mathrm{m} / \mathrm{z})$ at 905.37 .

\section{Preparation of an azete derivative}

Several studies have showed the preparation of some azete analogs using some reagents such as $\mathrm{Rh}_{2}(\mathrm{OAc})_{4}$ [31], $\mathrm{N}$-nitrenes [32], 2,3-dibromopropylamine [33], 1-aminoacetylenes [34]. In this investigation, an azete derivative (9) was synthesized. This stage was achieved via $2+2$ addition of 6 to compound 7 in the presence of copper(II) chloride (Figure 5). The ${ }^{1} \mathrm{H}$ NMR spectra from 9 showed several signals at 1.00-1.30, 1.62, 1.94-2.35, 2.82, 3.90-3.94 and 5.50-6.74 ppm for 2-Oxa-bicyclo[7.3.1]trideca-1(12),9(13),10-trien-7-yne fragments; at 1.52, $1.68,2.72$ and $4.12 \mathrm{ppm}$ for methylene groups bound to both azete ring and ether group; at 3.70 ppm for methylene group bound to azete ring; at $4.96 \mathrm{ppm}$ for azete ring; at 6.90-6.96 ppm for phenyl group; at 7.40-8.18 ppm for naphthalene fragments. ${ }^{13} \mathrm{C}$ NMR spectra showed chemical shifts at 19.20, 25.80-26.62, 67.34, 78.36-109.20, 113.12, 125.68, 117.42-125.62, 129.92, 157.54-161.64 and 163.32-164.24 ppm for 2-Oxa-bicyclo[7.3.1]trideca-1(12),9(13),10-trien7-yne fragments; at 21.90, 28.00-31.34 and $68.50 \mathrm{ppm}$ for methylene groups bound to both azete ring and ether group; at $45.54 \mathrm{ppm}$ for methylene group bound to azete ring; at 11.34, 153.60 and $165.90 \mathrm{ppm}$ for azete ring; at 115.70, 126.17, 126.55 and $162.08 \mathrm{ppm}$ for phenyl group; at 115.84, 117.78, 126.20-126.50, 128.34 and 130.80-150.74 ppm for naphthalene fragments. Besides, the mass spectrum from 9 displays a molecular ion $(\mathrm{m} / \mathrm{z})$ at 855.35.
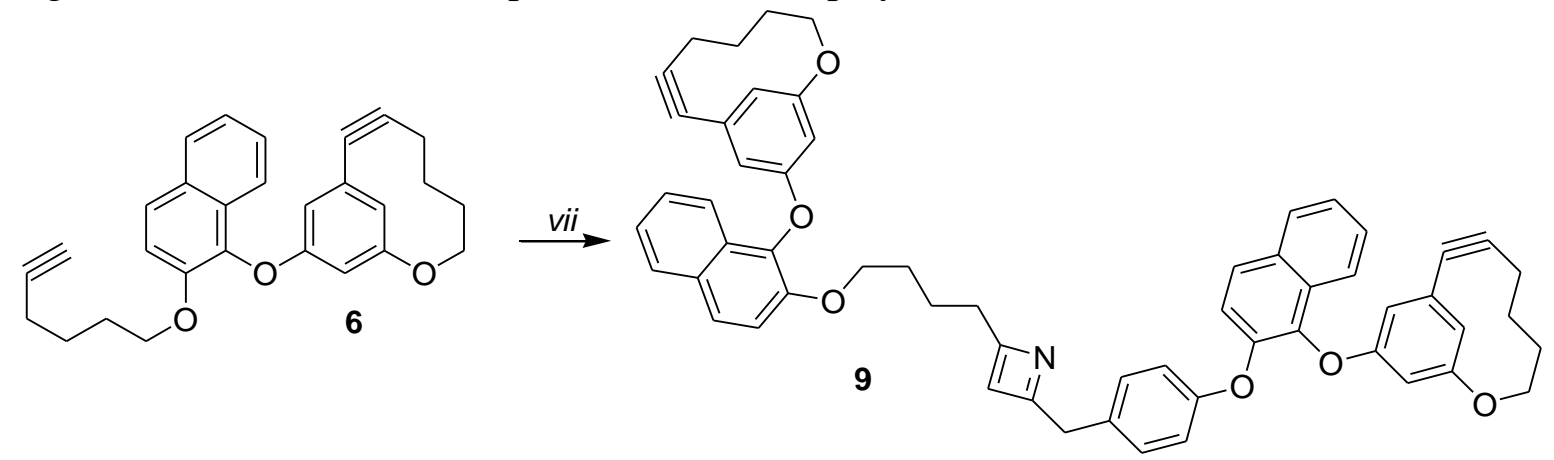

Figure 5. Synthesis of a 2-naphthyl-oxy-phenyl-methyl-azete derivative (9). Reagents and conditions: vii $=2-$ oxa-bicyclo[7.3.1]trideca-1(12),9(13),10-trien-7-yne derivative (6), naphthalen-2-yloxy]-phenyl\}-acetonitrile derivative (7), Copper(II) chloride, room temperature.

\subsection{Electronic factors.}

The molecular orbitals and their physicochemical properties, such as energy and the frontier electronic density, have been used to predict the reactivity of several compounds, which involves the $\pi$-electron system and several types of reactions on conjugated systems [35]. Some studies suggest that the highest occupied molecular orbital (HOMO) and lowest unoccupied molecular orbital (LUMO) values and their energy gap could be related to the 
chemical activity of several compounds. By analyzing these data, both HOMO and LUMO involved in the chemical structure of either compounds $\mathbf{8}$ or $\mathbf{9}$ were evaluated in this study. The results showed that the HOMO-LUMO gap values were different for $\mathbf{8}$ compared to 9 (Figure 6 and Table 1). This process could be conditioned by $\pi$ orbital, which is localized in either 2,3Dihydro-azete or azete rings.
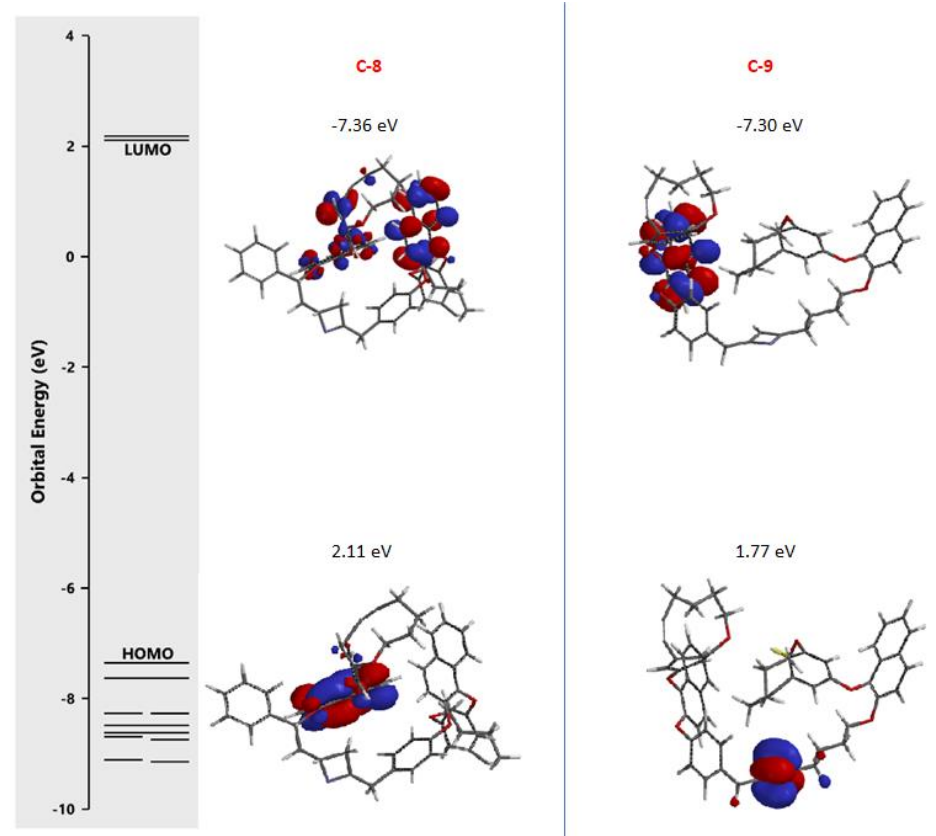

Figure 6. Molecular orbitals (HOMO and LUMO) involved in the compounds 8 (left) and 9 (right), visualized with SPARTAN'06 software

Table 1. Physicochemical parameters involved in the chemical structure of compounds $\mathbf{8}$ and $\mathbf{9}$. The values were calculated using Spartan software.

Parameters

Compounds

\begin{tabular}{|c|c|c|}
\hline & \multicolumn{2}{|r|}{ thes } \\
\hline & 8 & 9 \\
\hline HOMO (eV) & -7.36 & -7.30 \\
\hline LUMO (eV) & 2.11 & 1.77 \\
\hline $\log P$ & 12.98 & 11.73 \\
\hline HBD & 0 & 0 \\
\hline HBA & 7 & 7 \\
\hline
\end{tabular}

\subsection{Pharmacophore ligand model.}

Some chemical models have been used to determine the three-dimensional orientation adopted by the functional groups of several compounds to predict its binding with different biomolecules [36]. In this way, in this research, a pharmacophore model for both compounds 8 and 9 was determined using the LigandScout 4.1 (Figure 7). The data indicate that functional groups of compounds 8 and 9 could interact via hydrophobic contacts, hydrogen bond acceptors, or hydrogen bond donors with some biomolecules. 

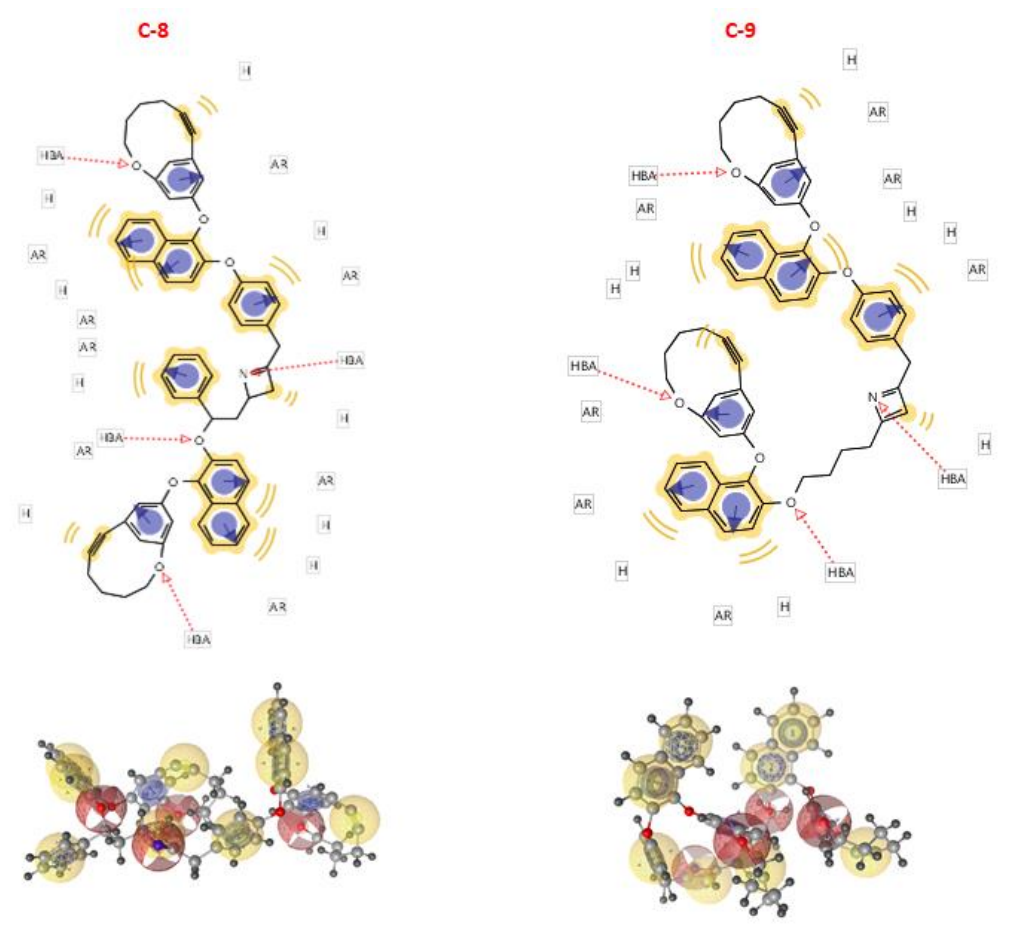

Figure 7. The scheme representing a pharmacophore from both compounds 8 (left) and 9(right) using the LigandScout 4.1 software. The model involves a methyl group (yellow), hydrogen bond acceptors (HBA, red) and hydrogen bond donor (HBD, yellow).

\section{Conclusions}

This research reports the synthesis of two azete derivatives that do not require special conditions to give a good yielding. Besides, the differences of parameters electronic such as HOMO and LUMO values and their energy gap may be associated with the chemical activity produced by these compounds; this is supported by other studies carried out in some biological models $[37,38]$.

\section{Funding}

This research received no external funding.

\section{Acknowledgments}

The authors acknowledge Benjamin Valverde and Raquel Anzurez for their unconditional support of this manuscript.

\section{Conflicts of Interest}

The authors declare no conflict of interest.

\section{References}

1. Didier, D.; Baumann, A.; Eisold, M. Unsaturated four-membered N-heterocycles: From synthesis to applications. Tetrahedron Letters 2018, 59, 3975-3987, https://doi.org/10.1016/j.tetlet.2018.09.055.

2. Kerru, N.; Gummidi, L.; Maddila, S.; Gangu, K.; Jonnalagadda, S. A review on recent advances in nitrogencontaining molecules and their biological applications. Molecules 2020, 25, 1909. https://doi.org/10.3390/molecules25081909.

3. Parshikov, I.; Silva, E.; Furtado, N. Transformation of saturated nitrogen-containing heterocyclic compounds by microorganisms. Applied Microbiology and Biotechnology 2014, 98, 1497-1506. 
4. Alcaide, B.; Almendros, P. Four-Membered Ring Systems. In Progress in Heterocyclic Chemistry 2012, 24,. 115-137).

5. Adger, B.; Keating, M.; Rees, C.; Storr, R. 2-Phenylbenzazete, an azacyclobutadiene. Journal of the Chemical Society, Chemical Communications 1973, 1, 19-20, https://doi.org/10.1039/C39730000019.

6. Nakamura, I.; Shiga, K.; Suzuki, M. Terada, M. Efficient synthesis of O-tert-propargylic oximes via Nicholas reaction. Synthesis 2020, 52, 3461-3465, https://doi.org/10.1055/s-0040-1707191.

7. Ledermann, M.; Regitz, M.; Angermund, K.; Binger, P.; Krüger, C.; Mynott, R.; Hyla-Kryspin, I. First Structure Analysis and Photoelectron Spectroscopic Investigation of an Azete and an Azete-Cobalt Complex. Angewandte Chemie International Edition 1988, 27, 1559-1562, https://doi.org/10.1002/anie.198815591.

8. Sulikowski, D.; Makosza, M. Synthesis of 3-Phenyl-2, 1-benzisoxazoles via Conversion of Diethyl $\alpha$-(oNitroaryl) benzylphosphonates. Acta Chimica Slovenica 2009, 56, 3.

9. Figueroa-Valverde, L.; Diaz-cedillo, F.; Rosas-Nexticapa, M.; Garcimarrero, A., Mateu, V. Facile synthesis of two azete-steroid derivatives and theoretical evaluation of its interaction with the aromatase enzyme. Hacettepe Journal of Biology and Chemistry 2019,47, 415-428. https://doi.org/10.15671/hjbc.602183.

10. Snieckus, V.; Board, J. Copper-Catalyzed Synthesis of 1, 4-Dihydroazete Derivatives. Synfacts 2012, 8, 1308-1308, https://doi.org/10.1055/s-0032-1317660.

11. Figueroa-Valverde, L.; Diaz-cedillo, F.; Lopez, M.; Rosas-Nexticapa, M.; Mateu, V.; Ake, Y. Design and synthesis of a bismethylsulfanyl-steroid-azetyl butanol derivative from 2-nitroestradiol. Journal of Heterocyclic Chemistry 2020, 57, 1737-1747. https://doi.org/10.1002/jhet.3899.

12. Abdullahi, M.; Uzairu, A.;Shallangwa, G.; Mamza, P.; Arthur, D.; Ibrahim, M. In-silico modelling studies on some C14-urea-tetrandrine derivatives as potent anti-cancer agents against prostate (PC3) cell line. Journal of King Saud University-Science 2020, 32, 770-779.

13. Olasupo, S.; Uzairu, A.; Adamu, G.; Uba, S. Computational modeling and pharmacokinetics/ADMET study of some arylpiperazine derivatives as novel antipsychotic agents targeting depression. Chemistry Africa 2020, 3, 979-988.

14. Shahzad, H.; Ahmadi, R.; Adhami, F.; Najafpour, J. Adsorption of cytarabine on the surface of fullerene C20: a comprehensive DFT study. Eurasian Chemical Communications 2020, 2, 162-169, https://doi.org/10.33945/SAMI/ECC.2020.2.1.

15. Isyaka, S.; Langat, M.; Mas-Claret, E.; Mbala, B.; Mvingu, B.; Mulholland, D. Ent-abietane and ent-pimarane diterpenoids from Croton mubango (Euphorbiaceae). Phytochemistry 2020, 170, 112217. https://doi.org/10.1016/j.phytochem.2019.112217.

16. Schaller, D.; Šribar, D.; Noonan, T.; Deng, L.; Nguyen, T.; Pach, S.; Wolber, G. Next generation 3D pharmacophore modeling. Wiley Interdisciplinary Reviews: Computational Molecular Science 2020, 10, e1468, https://doi.org/10.1002/wcms.1468.

17. Porey, S.; Zhang, X.; Bhowmick, S.; Kumar S.; Guin, S.; Paton, R.; Maiti, D. Alkyne linchpin strategy for drug: pharmacophore conjugation: Experimental and computational realization of a meta-selective inverse sonogashira coupling. Journal of the American Chemical Society 2020,142, 3762-3774, https://doi.org/10.1021/jacs.9b10646

18. Mascarenhas, A.; De Almeida, R.; De Araujo, M.; Mendes, G.; Da- Cruz, J.; Dos-Santos, C.; Leite, F.; Pharmacophore-based virtual screening and molecular docking to identify promising dual inhibitors of human acetylcholinesterase and butyrylcholinesterase. Journal of Biomolecular Structure and Dynamics 2020, 1-10, https://doi.org/10.1080/07391102.2020.1796791.

19. Davies, K.; Abel, R.; Wulff, J. Operationally Simple Copper-Promoted Coupling of Terminal Alkynes with Benzyl Halides. The Journal of organic chemistry 2009, 74, 3997-4000, https://doi.org/10.1021/jo900444x.

20. Zhang, H.; Sun, N.; Hu, B.; Shen, Z.; Hu, X.; Jin, L. Copper-catalyzed direct couplings of terminal alkynes with primary and secondary benzyl bromides. Organic Chemistry Frontiers 2019, 6, 1983-1988, https://doi.org/10.1039/C9QO00335E.

21. Li, C.; Li, W.; Wang, J. Gold (I)-catalyzed arylmethylation of terminal alkynes. Tetrahedron Letters 2009, 50, 2533-2535, https://doi.org/10.1016/j.tetlet.2009.03.067.

22. Cao, Y.; Dong, X.; Yang, J.; Jiang, S.; Zhou, S.; Li, Z.; Liu, X. A Copper-Catalyzed Sonogashira Coupling Reaction of Diverse Activated Alkyl Halides with Terminal Alkynes Under Ambient Conditions. Advanced Synthesis \& Catalysis 2020, 362, 2280-2284, https://doi.org/10.1002/adsc.202000189. 
23. Kanakikodi, K.; Churipard, S.; Shanbhag, G.; Halgeri, A.; Raju, C.; Valavarasu, G.; Maradur, S. Exploring the acidity of a functionalized mesoporous polymer catalyst (P-SO $3 \mathrm{H}$ ) for glycerol tert-butyl ether synthesis. Sustainable Energy \& Fuels 2020, 4, 6299-6310, https://doi.org/10.1039/D0SE01262A.

24. Yearty, K.; Maynard, R.; Cortes, C.; Morrison, R. A multioutcome experiment for the Williamson ether synthesis. Journal of Chemical Education 2020, 97, 578-581. https://doi.org/10.1021/acs.jchemed.9b00503.

25. Polierer, S.; Guse, D.;Wild, S.; Herrera, K.; Otto, T.; Zevaco, T.; Pitter, S. Enhanced Direct Dimethyl Ether Synthesis from CO2-Rich Syngas with $\mathrm{Cu} / \mathrm{ZnO} / \mathrm{ZrO} 2$ Catalysts Prepared by Continuous CoPrecipitation. Catalysts 2020, 10, 816, https://doi.org/10.3390/catal10080816.

26. Kikelj, D. Recent progress in diaryl ether synthesis. Synthesis 2006, 14, 2271-2285, https://doi.org/10.1055/s-2006-942440.

27. Figueroa-Valverde, L.; Lopez, M.; Diaz-Cedillo, F.; Rosas-Nexticapa, M.; Mateu, V.; Garcimarrero, A.; Ake, Y. Design and synthesis of new azetidine-steroid derivative with inotropic activity in a heart failure model. Vietnam Journal of Chemistry 2020, 58, 10-19, https://doi.org/10.1002/vjch.201900131.

28. Prieto, A. Synthesis of Four-Membered Aza-Heterocycles through Catalytic [2+2] Cycloaddition Reactions Assisted by Metal Complexes. Synthetic Approaches to Nonaromatic Nitrogen Heterocycles 2020, 37-58, https://doi.org/10.1002/9781119708841.ch3.

29. Andresini, M.; Degennaro, L.; Luisi, R. The renaissance of strained 1-azabicyclo [1.1. 0] butanes as useful reagents for the synthesis of functionalized azetidines. Organic \& Biomolecular Chemistry 2020, 18, 57985810, https://doi.org/10.1039/D0OB01251C.

30. Singh, G.; Advances in synthesis and chemistry of azetidines. Advances in Heterocyclic Chemistry 2020, 130, 1-74. https://doi.org/10.1016/bs.aihch.2019.10.001.

31. Smetanin, I.; Novikov, M.; Rostovskii, N.; Khlebnikov, A.; Starova, G.; Yufit, D. 4-Halo-2-azabuta-1, 3dienes as Intermediates in the rhodium carbenoid-initiated transformation of 2-halo-2H-azirines into 2, 3dihydroazetes and 2, 5-dihydrooxazoles. Tetrahedron $\quad \mathbf{2 0 1 5}, 71, \quad$ 4616-4628. https://doi.org/10.1016/j.tet.2015.05.022.

32. Rees, C.; Storr, R. Interconversions of some nitrogen-containing heterocyclic systems. Chemistry of Heterocyclic Compounds 1974, 10, 629-639.

33. Gensler, W. Investigation of the Compound Described as Azacyclobutadiene. Journal of the American Chemical Society 1974, 69(8), 1966-1968. https://doi.org/10.1021/ja01200a038.

34. Pennings, M.; Okay, G.; Reinhoudt, D.; Harkema, S.; Van-Hummel, G. Chemistry of four-membered cyclic nitrones. 2. 1, 3-Dipolar cycloaddition reactions with electron-deficient acetylenes and conversion of the 1, 3-dipolar adducts into pyridine derivatives. The Journal of Organic Chemistry 1982, 47, 44134418.https://doi.org/10.1021/jo00349a004.

35. Figueroa-Valverde, L.; Díaz-Cedillo, F.; Garcia-Cervera, E. Synthesis of two steroids derivatives and its relationship with some physicochemical parameters. E-Journal of Chemistry 2012,9, 27-34, https://doi.org/10.1155/2012/481769.

36. Schneider, G.; Neidhart, W.; Giller, T.; Schmid, G. Scaffold-hopping" by topological pharmacophore search: a contribution to virtual screening. Angewandte Chemie International Edition 1999, 38, 2894-2896, https://doi.org/10.1002/(SICI)1521-3773(19991004)38:19<2894::AID-ANIE2894>3.0.CO;2-F.

37. Chaviara, A.; Kioseoglou, E.; Pantazaki, A.; Tsipis, A.; Karipidis, P.; Kyriakidis, D.; Bolos, C. DNA interaction studies and evaluation of biological activity of homo-and hetero-trihalide mononuclear $\mathrm{Cu}$ (II) Schiff base complexes. Quantitative structure-activity relationships. Journal of inorganic biochemistry 2008, 102(9), 1749-1764. https://doi.org/10.1016/j.jinorgbio.2008.05.005

38. Mabkhot, Y.; Aldawsari, F.; Al-Showiman, S.; Barakat, A.; Soliman, S.; Choudhary, M.; Hadda, T. Novel enaminone derived from thieno [2, 3-b] thiene: Synthesis, x-ray crystal structure, HOMO, LUMO, NBO analyses and biological activity. Chemistry Central Journal 2015, 9(1), 1-11. 